Itinéraires Itinéraires

Littérature, textes, cultures

2015-2 | 2016

Stumbling blocks. Entraves et obstacles aux circulations

\title{
Transposition and Adaptation of Models in Post- Conflict Northern Ireland: The Personal Experience of Brandon Hamber
}

Transposition et adaptation de modèles dans l'Irlande du Nord post-conflit:

l'expérience personnelle de Brandon Hamber

\section{Fabrice Mourlon}

\section{(2) OpenEdition}

\section{Journals}

\section{Electronic version}

URL: http://journals.openedition.org/itineraires/2876

DOI: 10.4000/itineraires.2876

ISSN: 2427-920X

Publisher

Pléiade

\section{Electronic reference}

Fabrice Mourlon, «Transposition and Adaptation of Models in Post-Conflict Northern Ireland: The Personal Experience of Brandon Hamber », Itinéraires [Online], 2015-2 | 2016, Online since 15 February 2016, connection on 21 April 2019. URL : http://journals.openedition.org/itineraires/2876 ; DOI : 10.4000/itineraires.2876

This text was automatically generated on 21 April 2019.

\section{cc) (†)}

Itinéraires est mis à disposition selon les termes de la licence Creative Commons Attribution - Pas d'Utilisation Commerciale - Pas de Modification 4.0 International. 


\title{
Transposition and Adaptation of Models in Post-Conflict Northern Ireland: The Personal Experience of Brandon Hamber
}

\author{
Transposition et adaptation de modèles dans l'Irlande du Nord post-conflit : \\ l'expérience personnelle de Brandon Hamber
}

\author{
Fabrice Mourlon
}

1 The conflict in Northern Ireland, which lasted from 1969 to 1998, has been defined as protracted or intractable (Ruane and Todd 2012) and, over that period, scholars have been striving to find a suitable interpretation to explain it. Yet, its manifold interpretations led some academics to conclude that "there is a meta-conflict about what the conflict is about" (McGarry and O'Leary 1995: 1) or that "there is no such single Northern Ireland problem, easily characterised and classified, as a set of interlocked and confused problems" (Dunn 1995: 7). In an essay published in 1995, John Darby claimed that the conflict was based on six interrelated issues among which the future constitutional position of Northern Ireland stood out (i.e. remaining within the UK, a united Ireland or independence). The other problems concerned social and economic inequalities between the so-called "Catholic-Nationalist-Republican" and "ProtestantUnionist-Loyalist" communities, as well as the question of their cultural identities and the relationships between each other. Finally the on-going violence and the problem of security was of importance. Concerning the constitutional issue, as early as 1974, the British government that had been administrating the statelet through Direct Rule since 1972, attempted to restore a devolved power which had been in place since 1921 when the six-county territory was created. By the early 1990s the seven attempts had all failed (Darby 1995). Reforms were also introduced in the fields of housing (Housing reading list), employment (Education reading list) and education (Smith 1999), which gave mixed results. A cross-community cooperation programme was launched under the terms of 
"community relations," notably in the mid-1980s (Carmichael and Hughes 1998). At the same time, political parties and paramilitary groups were gradually changing their perspectives on the conflict. They also formed new alliances, often through secret talks that also took place with the British and Irish governments. In the early 1990s the protagonists in the conflict realised that violence would not resolve their disagreements on communal identity, politics and the future constitutional status of the province. In 1998, an agreement was reached to gradually put an end to violence and devise powersharing institutions that would suit each party. The Belfast Agreement of 1998 was ratified by a majority of the population both in Northern Ireland and in the Republic of Ireland. However, the devolved assembly and government collapsed after clashes between political parties and were only reestablished in 2008. This chaotic road to a "relative peace" is due to the work of both internal and external actors.

2 If one considers how external actors and models have influenced or shaped the peace process in Northern Ireland, Richard Haass's ${ }^{1}$ role as mediator in the multi-party talks of 2013 on contentious issues of parades, commemorations, flags and emblems and dealing with the past, represents one of the latest examples (An Agreement 2013). The intervention of third parties, especially from the US, is a regular feature of the on-going peace process in Northern Ireland. Indeed, the very essence of power-sharing institutions that seek consensus between opposed political parties and interests plunges political life into periodic crises, which often require outside intervention to reach a settlement. Literature on the role of the US in Northern Ireland is well documented and highlights the political, economic and domestic self-interests of such mediations (MacGinty 1997). Literature on mediation in general has focused on the timing of negotiations, who was involved in the process and what techniques and methods were used (Breen Smyth 2014). It also reveals the power relations at play, the role of various actors and how to keep momentum in the talks, i.e. how to maintain dialogue between the various protagonists.

3 However, many examples of external third parties' experience have been drawn from the elite level according to John-Paul Lederach's model of peace-building (Lederach 1997). The function of middle-ground people in peace processes is favoured in his model as they have the capacity to influence and link the elite and grassroots levels. Other theorists such as Joseph Montville (1986) have called this middle ground "Track-Two diplomacy" which involves professional, non-governmental practitioners and theorists usually drawn from NGOs and academia. Paul Arthur wrote about his experience in this type of diplomacy and defined it as follows:

Track-Two diplomacy comes [...] in the interstices between "high politics" (strategy steered by politicians and officials) and "low politics" (the adaptation of civil society). It seeks to promote an environment in a political community, through the education of public opinion, that would make it safer for public opinion to take risks for peace. (Arthur 2009: 20)

4 It is an unofficial process that has positive effects on the formal political negotiations, with meetings usually held outside the country with no media attention. And yet, the examples he gives tend to concentrate on meetings between representatives of political parties and his descriptions are mainly concerned with technical considerations. For instance, he explains the need to find "sufficient concerns" between the opposing groups, the significance of setting up special committees on highly politicized issues, or the methodology used to enable each side to tell their story and learn from different contexts. These unofficial talks tend to encourage trust among politicians while official 
negotiations are being scrutinized by the media putting much pressure on the actors to deliver a settlement.

5 All these examples of mediations, either at the elite or the middle-ground level, tend to portray professionals from outside the country where the conflict is happening. This paper wishes to look at the itinerary and personal experience of Brandon Hamber, a South African-born academic who settled in Northern Ireland in the early 1990s and who has been involved in shaping the debate on dealing with the past. After working with several community groups and government bodies involved in the peace process he is now Director of the International Conflict Research Institute (INCORE) at the University of Ulster. His position as a middle-ground practitioner and both an outsider and insider in the Northern Irish context is an interesting example of how the process of shaping policies and of transferring models across various contexts can be facilitated or hindered.

\section{Lesson Drawing and Policy Transfer}

6 In the early 2000s, Brandon Hamber and other academics at the International Conflict Research Institute (INCORE) ${ }^{2}$ reflected on the processes of "lesson drawing" and "lesson transfer" from South Africa to Northern Ireland. They had come to the realisation that comparative studies did not delve adequately into research on public policy, and so launched a research project: "Developing and Implementing Public Policy" in Northern Ireland and South Africa (Broclehurst, Stott and Hamber 2000). Their conclusions will serve as a theoretical framework to analyse and describe Brandon Hamber's experience.

7 The specific context of the research was that of two transitional societies in which the authors were considering whether lessons could be transferred cross-culturally and cross-contextually. They pointed out that the term "transitional societies" in itself posed a problem as it was not easily defined. According to them, it is a complex political and socially constructed term in contexts that are marked by uncertainty and social instability, in which research by academics could act as a stabilizing force and provide objective conceptual clarity and direction. In turn the context itself shaped the way research would be used and transferred, and the process depended on the complex relationship between researchers and policymakers.

Generally speaking, policymakers are not necessarily concerned about whether lessons are transferred in a comprehensive way. In the early phase of transition they are under pressure to come up with adequate policies and they usually look at other countries for models. At this stage, time for reflection is minimal and policies designed in other countries are likely to be transferred in an unconstructed manner. They do not always use research and empirical evidence, and if they do, these tend to support their current policy's approach on a given issue. Because research produces complex and contradictory results, policymakers tend to "rationalize" or "compartmentalize" them into their political measures (Broclehurst, Stott and Hamber 2000: 11-13). ${ }^{3}$

On the other hand, the impact of academics' research depends on their ability to disseminate their results outside the realm of conferences where most ideas are shared. Their influence is often due to unpredicted and unintended meetings with policymakers. As a result, researchers' and policymakers' agendas rarely coincide. In the case of Northern Ireland and South Africa, the authors concluded that the role of research in the policy transfer process was often limited as policy makers did not use it in a consistent 
way and research could not reach out to a wider audience. Also, the position of researchers in either country differed considerably. In the 1980s and 1990s in South Africa, academics were encouraged to be activists in civil society, whereas in Northern Ireland researchers were more distant and only got involved more visibly in the public debate 4 in the post-conflict period. Policy transfer is then a "disorganised," "selective" and "arbitrary" process (Broclehurst, Stott and Hamber 2000). That is why the authors call for academics to engage in micro debates and micro events within civil society to influence public opinion and indirectly public policy. This is the line that Brandon Hamber followed as both an outsider and insider in Northern Ireland.

\section{Brandon Hamber's Position}

Within the different layers of people's involvement at cross-national level, Brandon Hamber describes himself as a man from the middle ground (Interview Hamber 2014). In South Africa he worked in and about the process of the Truth and Reconciliation Commission between 1995 and 2003. At that period he worked for the Centre for the Study of Violence and Reconciliation (CSVR) in Johannesburg (1995-2001). He continued to do research and to work on the ground around the issue of dealing with the past in Northern Ireland and at the international level. His experience and training as a psychodynamic psychotherapist, using concepts borrowed from Melanie Klein and Donald Winnicott, have influenced his theory and practice. He qualifies his experience as being that of "an observer, a participant, a researcher, an activist and an action researcher" (Hamber 2009: 5). His attitude to knowledge is about "the importance of uncovering the process of knowledge generation in order to understand what is revealed through it [...]. The construction of knowledge resides not in individuals but in the relations between individuals" (Hamber 2009: 3). Hence the importance of his intellectual and practical involvement in the settings where he lived and worked, and the people he was in contact with when he tried to influence policymaking.

11 He first came to Northern Ireland in 1996 when Cyril Ramaphosa, a South African politician, came to visit prisoners at Long Kesh/The Maze ${ }^{5}$ to talk about the potential of having a peace process. He was invited unofficially at the request of a Quaker group to address the psychological issues met by inmates. He came back again for a conference and spent six months in Northern Ireland with a scholarship at INCORE. He then met victims groups and funding organisations and was involved in the early civil society conferences on comparative peace agreements. This led to the publication of Past Imperfect on how to deal with the past (Hamber 1998). The volume gathers contributions by people from Northern Ireland, South Africa and Guatemala. After travelling back and forth between South Africa and Northern Ireland, he settled permanently in Derry in 2002 for practical and personal reasons. He had met his wife and thought that there was a lot of work to be done on the issue of dealing with the past. He decided to work as an independent consultant as he wanted to remain neutral and did not want to be seen as being aligned with one community or the other. He also wished to stay away from the media. Until now, Brandon Hamber has been a consultant with over fifty groups and institutions ranging from political organisations such as Democratic Dialogue, to voluntary organisations such as the Conflict Trauma Resource Centre, Relatives for Justice, Ulster Prisoners Aid, as well as public organisations such as the Victims Liaison Unit or SEUPB (the body in charge of European programmes in Northern Ireland). 


\section{A Favourable Context for Lesson Drawing} exchange of views and opinions between transitional societies. Already in the 1980s, South Africa and Northern Ireland had been systematically compared by academics such as Adrian Guelke (2012), Alan Johnston, John Darby and Roger McGinty (Brocklehurst, Stott and Hamber 2000: 3-5). On the ground, many actors in the peace process in Northern Ireland were looking at other post-conflict societies for models (Brocklehurst, Stott and Hamber 2000: 6-8). Learning from other experiences was also embodied in the foundation of INCORE and the Developing and Implementing Public Policy project. ${ }^{6}$ Indeed, INCORE was established in 1993 as a joint initiative from the United Nations University and the University of Ulster. It has a pluridisciplinary approach to conflictresolution research and works with both local and international institutions and organisations:

Combining research, education and comparative analysis, INCORE addresses the causes and consequences of conflict in Northern Ireland and internationally and promotes conflict resolution management strategies. It aims to influence policymakers and practitioners involved in peace, conflict and reconciliation issues while enhancing the nature of international conflict research. ${ }^{7}$

Similarly, the organisation Healing Through Remembering that has been influential in shaping the debate on dealing with the past, was created after the visit of Alex Boraine, Deputy Chairman of the Truth and Reconciliation Commission in South Africa, to Northern Ireland in 1999 (All Truth Is Bitter 2000). Since then, the organisation has produced around thirty reports on the issue and participated in the governmentsponsored consultations (HTR Reports). Civil society and the voluntary sector pushed for the debate on how to deal with the past to be taken into account both within their own ranks and at government level. In 1998, two conferences were organised on the subject. The Dealing with the Past: Reconciliation Processes and Peace-Building Conference was hosted by INCORE in June 1998 in Belfast and funded by the Community Relations Council and the Central Community Relations Unit. Gathering various experts from different backgrounds and countries such as South Africa and Guatemala, the participants explored possible ways for Northern Ireland to engage in "remembering" activities and in the creation of a Truth and Reconciliation Commission. The Northern Ireland Voluntary Trust/Community Foundation Northern Ireland ${ }^{8}$ also organised conferences fostering the exchange of experiences from various settings around the world (Magowan and Patterson 2001). It also has various comparative civil society programmes, such as the "Conflict Transformation from Bottom Up," "Communities in Transition" or "Prison to PeaceBuilding on Experience Partnership." The Commission for Victims set up in 1997 to look at how to provide support to victims of the conflict also examined the various policies set up in other countries (Bloomfield 1998). Looking at how to best recognise the victims and survivors, the Commission considered the experience of the US, Spain, Israel and South Africa.

Nowadays, the voluntary sector is still involved in exchanges with other countries and so are politicians (Mourlon 2012). The early aftermath of the Belfast Agreement seemed conducive to an open debate on how to move away from a divided violent society, which includes finding mechanisms to deal with the past. 


\section{Brandon Hamber and Dealing with the Past in Northern Ireland}

With his experience with the South African transitional society, Brandon Hamber knew that the issue of how to deal with the past would come to the fore. But when he first raised the question in his publication Past Imperfect (Hamber 1999), he was met with very negative and hostile reactions: "people thought I was strange even to ask the question" (Interview Hamber 2014). In fact addressing this issue was difficult and potentially divisive as the negotiations on the peace process were still fragile. Politicians were more concerned about constitutional and institutional arrangements in the province and the problems around the release of political prisoners, the reform of the police force and the justice system.

16 Brandon Hamber once again raised the issue when he joined Healing Through Remembering (HTR) in 2001 as a consultant. Together with Kate Turner, they facilitated early discussions within the organisation. He recalls that during the first meeting, participants from different communities did not want to stay in the same room and the atmosphere was tense and aggressive: "Why do you want to talk about dealing with the past. We're not ready for that" was the typical reaction he got.

17 His idea was to keep participants talking and debating through their commitment to a set number of meetings and to the idea that they did not need to agree. These initial meetings led HTR to conduct the first large-scale consultation on the topic, with the first HTR report published in 2002 analysing the pros and cons of devising and implementing mechanisms to address the violent past. They found out that views were divided on how to examine the past:

Many of the submissions endorsed the value of remembering and spoke of the importance of finding ways to move society forward. At the same time, others expressed their concerns about the potential pitfalls of remembering. Clearly, the idea of remembering also evoked an emotive response, suggesting that much hurt and unresolved pain is still present. (HTR 2002: v)

They made six recommendations for the future, including putting in place a storytelling process, fixing a Day of Reflection, creating a living memorial museum, ensuring that the protagonists in the conflict acknowledged their responsibility.

There is no single treatment for the healing process. Processes of remembering, reflecting, informing and educating must be sustained for another generation at least. All have a part to play in dealing with the memories of the past. This will be a painful and difficult task, however it should not paralyse us and prevent us from moving on, but encourage us to avoid further damage, seek solutions and create a better future. (HTR 2002: introduction VII)

19 In his everyday practice one way of going round contentious issues lay in the use of a particular method that Brandon Hamber coined as "talking about issues in a surrogate way":

If you talk about policies developed elsewhere, people will gradually talk about their own country as the attention is initially diverted on something else and not on the bone of contention. (Interview Hamber 2014)

20 However, his nationality was in itself a chilling factor in fostering debate. He became aware that people assumed that if you were South African and addressing the past you 
were promoting a Truth and Reconciliation model. These assumptions were reinforced in the early stages of the peace negotiations in 1998 when South Africa "was enjoying a sort of honeymoon" as it was clearly identified as the model to follow. Brandon Hamber recalls that South Africa became "an ideal symbolic discussion" and people in Northern Ireland usually projected their own feeling on the situation there, which they usually understood through "misconceived analysis." Also being a South African was seen as being predisposed towards the nationalist community because of the historical links between Sinn Fein and the ANC (Brocklehurst, Stott and Hamber 2000). This perception can also be explained in a wider context. Not only have South African and Northern Ireland societies been compared by researchers since the late 1980s and early 1990 s (Brocklehurst, Stott and Hamber 2000: 3), ${ }^{9}$ but both countries share a common and entangled history of shifting alliances (Lodge 2006). While some Irish nationalists fought on the side of the Boers during the Second Boer War (1899-1902), which was a way to fight the British Empire by proxy, the Irish Republican movement clearly identified with the ANC's "liberation strategy" by the 1970s. On the other hand, while Irish Unionists had supported the British Empire in the early twentieth century, some loyalist paramilitary groups established links with Afrikaner groups in the 1980s. Besides both republicans and loyalists were involved in arms exchanges (Dorney 2013, McDonald 2004, O'Caroll 2013) ${ }^{10}$ and training in explosives. ${ }^{11}$

Interestingly enough, another South African-born academic at Queen's University, Professor Adrian Guelke, was wrongly suspected of having connections with the Republican movement in the 1990s. He has written both about Northern Ireland in a comparative perspective with South Africa and on the Apartheid regime and has always been opposed to republican violence during the Troubles. However, on 4 September 1991 he was the victim of an attempted murder carried out by a UDA gunman. The attack was organised by the South African Defence Forces' intelligence branch which had used a doctored RUC intelligence report claiming that Guelke had links with the IRA and the ANC. The document had in fact been falsified by Leon Flores, a South African agent who wanted to set Guelke up (McDonald 2004).

In this context, Hamber's involvement in the debate on how to deal with the past was met with resistance and gave mixed results. Seven years ago, reluctance towards him was still tangible when he was interviewed by the Northern Ireland Affairs Committee in 2008. At that time criticism was based on the fact that he was perceived as being part of an intellectual elite:

Dr Hamber: [...] One of the biggest challenges within the process of dealing with the past is that you have a whole range of people with a whole range of different needs, so it is very difficult to do one thing that would meet all of those needs. [...] When I talk about the issue of acknowledgment, I mean it as a wider, social and political process of people engaging in the past and saying, "Yes, there is something that we need to acknowledge in relation to the way that it happened," whether that is acts of omission or commission. It is a much wider level I am talking about at a political level.

Q274 Kate Hoey: Are you sure it is not just academics and well meaning people thinking this is what people want when maybe it is not?

Q282 Chairman: You have come to Northern Ireland, you have set up this organisation and are acting as our tutor in these matters, surely you have a view.

Q288 Mr Hepburn: There are a lot of Sir Kenneths about and, with all respect, Dr Hamber, academics who are telling working class people in the Falls Road and 
Shankill Road what they need. Can you tell me why you think that your way out is what these people actually need? (House of Commons 2008) Hamber's position that he relentlessly put forward over the years:

This book does not prescribe a single method that should be used for dealing with the past. It is postulated that the debate should not be whether Northern Ireland should have a South African style truth commission or not, but rather, what strategy (or strategies) NI should be considering for dealing with the past. (Hamber 1998: 2)

One criticism I would have of the South African approach was an over-reliance on stressing that the South African TRC as the primary mechanism for dealing with the past, when clearly a range of mechanisms were going to be necessary over a long period of time. (Northern Ireland Affairs Committee 2004-05)

So being an outsider associated with the South-African model somewhat hindered his influence that took twelve years to be eventually seen as legitimate. Although reexamining the past is still a contentious issue that divides political parties in power, Brandon Hamber and the voluntary sector were influential in fostering debate at the elite level. Some mechanisms in spite of being piecemeal have been put in place. At least two official consultations were organised on the subject by the Northern Ireland Affairs Committee in the House of Commons in 2005 and by the Consultative Group on the Past in 2009 (CGP 2009). The British government set up Public Inquiries into past violence, the most mediatised of which being the Saville Inquiry into the events of Bloody Sunday. Within the new police service, two bodies were charged with re-examining unsolved deaths: the Historical Enquiry Team and the Office of the Police Ombudsman. The fate of the "Disappeared," people from the Catholic/Nationalist community who had been murdered by the IRA or INLA, is being addressed by the Commission for the Location of Victims' Remains. These investigative bodies are complemented by other judicial procedures such as Coroner's Inquests and Civil cases (Mourlon 2012). The lack of agreement on how to proceed with an overarching and coordinated body that would deal with past violent event explains this multiplication of bodies and commissions.

This issue is an integral part of the reconciliation process that has been on the agenda in government policy documents and in the successive European Peace Programmes.

\section{Reconciliation}

The fact that reconciliation, as an outcome of the peace process, is an ill-defined concept and practical tool has been analysed. It has been seen as being imposed by official policy papers emanating from the government and the European Union. Among others, Brandon Hamber and Grainne Kelly revealed that the term used in the Belfast Agreement and given priority in the European Peace II programme was loosely defined (Kelly and Hamber 2005, Hamber and Kelly 2005, Harvey 2003). They proceeded with a consultation of stakeholders in Northern Ireland and came up with the following working definition of reconciliation:

Developing a shared vision of an interdependent and fair society

Acknowledging and dealing with the past

Building positive relationships

Significant cultural and attitudinal change

Substantial social, economic and political change. (Hamber and Kelly 2005: 36-40) 

coming out of violence and divisions, governments and the voluntary organisations tend to look at other possible models to resolve conflict. However well-established peacebuilding theories are, processes on the ground reveal resistance to the transfer of lessons from abroad and the need for adaptation. Brandon Hamber, having been involved in two transitional societies, provides a good example of the difficulties of cultural and policy transfer. However his very position at the heart of policymaking explains his achievements in influencing the debate on dealing with the past and reconciliation in Northern Ireland. As a member of an NGO he had worked for the South African TRC which in his own words had "sucked in most people from the voluntary sector." He then realised the importance of this sector and his main achievement in Northern Ireland has been to "engage in processes and maintain a civil society presence in the debate about dealing with the past." He realised that this issue was a long-term and chaotic process and that reconciliation was about living with unresolved issues, i.e. learning to live with paradoxes. Keeping momentum on these issues has been his main accomplishment in Northern Ireland. 


\section{BIBLIOGRAPHY}

Arthur, Paul, 2009, "Reciprocity and Recognition: Exercise in Track Two Diplomacy," in J. J. Popiolkowski and N. J. Cull (eds), Public Diplomacy, Cultural Interventions and the Peace Process in Northern Ireland: Track Two to Peace?, Los Angeles, Figueroa Press.

Bloomfield, Kenneth, 1998, We Will Remember Them, Belfast, The Stationery Office Northern Ireland.

Breen Smyth, Marie, 2014, "The Role of Third Parties in Political Settlements: a Comparative Analysis of the Sri Lanka and Northern Ireland Peace Processes," Unpublished conference delivered on 11 March 2014 at a seminar "Médiation et exclusion : la place du tiers dans la fabrique du lien social," Villetaneuse, Université Paris 13.

Brocklehurst, Helen, Stott, Noel and Hamber, Brandon, 2000, "Lesson Drawing from Negotiated Transitions in Northern Ireland and South Africa," paper delivered at the 2000 Annual Meeting of the American Political Science Association, Marriot Wardman Park, August 31-September 3, 2000, [Online], http://www.incore.ulst.ac.uk/publications/pdf/APSAHamberBran.pdf, accessed on 8 October 2014.

Carmichael, Paul and Hughes, Joanne, 1998, "Community Relations in Northern Ireland: Attitudes to Contact and Integration," in G. Robinson et al. (ed.), Social Attitudes in Northern Ireland: The Seventh Report, Hants, Ashgate Publishing, p. 1-19.

Consultative Group on the Past, 2009, Report of the Consultative Group on the Past, Belfast, CGP.

Darby, John, 1995, “Conflict in Northern Ireland: A Background Essay," in S. Dunn (ed.), Facets of the Conflict in Northern Ireland, London, Macmillan Press, p. 15-23.

Dorney, John, 2013, «Ireland and South African Politics - A tangled History », The Irish Story, [Online], http://www.theirishstory.com/2013/12/06/ireland-and-south-african-politics-atangled-history/\#.VUCalFvkjPu, accessed on 28 April 2015.

Dunn, Seamus (ed.), 1995, Facets of the Conflict in Northern Ireland, London, Macmillan Press.

Employment reading list: http://cain.ulst.ac.uk/issues/employ/employ.htm, accessed on 27 April 2015.

EU Programme for Peace and Reconciliation (PEACE III), 2007-2013, Northern Ireland and the Border Region of Ireland. Draft Operational Programme, Belfast, SEUBP, January 2007.

Great Britain. Northern Ireland Office, 1998, The Belfast Agreement: an agreement reached at the multi-party talks on Northern Ireland, Cm 3883, London, Stationery Office, 20 April 1998.

Guelke, Adrian, 2012, Politics in Deeply Divided Societies, Cambridge, Polity Press.

Haass, Richard and O'Sullivan, Meghan, 2013, Proposed Agreement 31st December 2013: An Agreement among the Parties of the Northern Ireland Executive on Parades, Select Commemorations, and Related Protests; Flags and Emblems and Contending with the Past, [Online], http://

www.northernireland.gov.uk/haass.pdf.

Hamber, Brandon (ed.), 1998, Past Imperfect: Dealing with the Past in Northern Ireland and Societies in Transition, Derry, Londonderry, INCORE. 
Hamber, Brandon, 2003, “Are lessons transferable? The importance of research for policy on transitional justice mechanisms," paper delivered at the "Empirical Research Methodologies of Transitional Justice Mechanism Conference," 18-20 November 2002, Stellenbosch, South Africa, 3 July 2003, [Online], http://www.brandonhamber.com/publications/pap-lessonstransferable.pdf , accessed on 8 October 2014.

Hamber, Brandon, 2009, Transforming Societies after Political Violence: Truth, Reconciliation and Mental Health, London, Springer.

Hamber, Brandon and Kelly, Grainne, 2005, A Place for Reconciliation? Conflict and Locality in Northern Ireland, Belfast, Democratic Dialogue, Report 18.

Harvey, Brian, 2003, Review of the Peace II Programme, The Joseph Rowntree Charitable Trust.

Healing Through Remembering Reports, Complete list: http://

www.healingthroughremembering.org/resources/reports/, accessed on 8 October 2014.

Healing Through Remembering, 2000, All Truth is Bitter: A Report of the Visit of Doctor Alex Boraine, Deputy Chairmain of the South African Truth and Reconciliation Commission, to Northern Ireland, Belfast, HTR, [Online], http://www.healingthroughremembering.org/images/pdf/ All_Truth_is_Bitter.pdf, accessed on 8 October 2014.

Healing Through Remembering, 2002, The Report of the Healing Through Remembering Project, Belfast, HTR., [Online], http://www.healingthroughremembering.org/images/pdf/htrreport.pdf, accessed on 8 October 2014.

House of Commons, Northern Ireland Affairs Committee, Minutes of Evidence, Wednesday 19 March 2008, Room 144, Stormont, Belfast, London, The Stationery Office, [Online], http:// cain.ulst.ac.uk/victims/docs/british_gov/ni_affairs_ctte_hc/niac_evidence_190308.pdf, accessed on 8 October 2014.

Housing reading list: http://cain.ulst.ac.uk/issues/housing/housing.htm, accessed on 27 April 2015.

Incore, http://www.incore.ulst.ac.uk/about/, accessed on 8 October 2014.

Incore, "Developing and Implementing Public Policy in Northern Ireland and South Africa (DIPP)," http://www.incore.ulst.ac.uk/research/projects/dipp/, accessed on 8 October 2014. Interview with Brandon Hamber in February 2014 at INCORE, Derry/Londonderry, Northern Ireland.

Johnston, Alan, 1990, "Self-determination in Comparative Perspective: Northern Ireland and South Africa," Politikon, vol. 17, no. 2, p. 5-22.

Kelly, Grainne and Hamber, Brandon, 2005, Reconciliation: Rhetoric or Relevant?, Belfast, Democratic Dialogue, Report 17.

Lederach, John Paul, 1997, Building Peace: Sustainable Reconciliation in Divided Societies, Washington DC, United States Institute of Peace Press.

Lodge, Tom, 2006, “An 'boks amach': the Irish Anti-Aparthied Movement," History Ireland, no. 4, http://www.historyireland.com/20th-century-contemporary-history/an-boks-amach-the-irishanti-apartheid-movement/, accessed on 30 April 2015.

MacGinty, Roger, 1997, “American Influences on the Northern Ireland Peace Process," Journal of Conflict Studies, vol. 17, no. 2, p. 31-50.

Magowan, James and Patterson, Norma (eds), 2001, Hear and Now...and Then..., Development in Victims and Survivors Work, Belfast, NIVT. 
McDonald, Henry, 2004, "The underbelly of a city of assassins," The Guardian, 3 October 2004, http://www.theguardian.com/uk/2004/oct/03/northernireland.northernireland1.

McGarry, John and O'Leary, Brendan, 1995, Explaining Northern Ireland, Oxford, Blackwell Publishers.

Montville, Joseph, 1986, Track Two Diplomacy: The Development of Non-Government Peace Promoting Relationships, Limerick, Irish Peace Institute.

Mourlon, Fabrice, 2012, "Official Responses to Dealing with the Past in Northern Ireland: Between Remembering and Forgetting," E-rea, no. 10.1, [Online], http://erea.revues.org/2857. DOI :

$10.4000 /$ erea. 2857

Northern Ireland Affairs Committee, Ways of Dealing with Northern Ireland's Past: Interim Report-Victims and Survivors Tenth Report of Session 2004-05, Vol. II.

O'Caroll, Colin, 2013, "Minister reveals how IRA agreed to train ANC's military wing MK," Belfast Telegraph, 07 December 2013, [Online], http://www.belfasttelegraph.co.uk/news/northernireland/minister-reveals-how-ira-agreed-to-train-ancs-military-wing-mk-29817973.html, accessed on 28 April 2015.

Ruane, Joseph and Todd, Jennifer, 2012, "Resolving Intractable Conflicts," Discussion Series no. 9: Patterns of Conflict Resolution, Dublin, Institute for British-Irish Studies, University College Dublin, [Online], http://www.ucd.ie/ibis/publications/discussionpapers/resolvingintractableconflicts/ Ruane_Todd.pdf, accessed on 8 October 2014.

Smith, Alan, 1999, "Education and the Peace Process in Northern Ireland," Paper presented to the Annual Conference of the American Education Research Association, Montreal, [Online], http:// cain.ulst.ac.uk/issues/education/docs/smith99.htm, accessed on 27 April 2015.

\section{NOTES}

1. American diplomat, United States Special Envoy for Northern Ireland who succeeded George J. Mitchell (1995-2001).

2. INCORE was established in 1993 by the United Nations University and the University of Ulster. It is located on the Magee Campus of the University of Ulster in Derry/Londonderry.

3. This means that policymakers do not consider research in their holistic and complex outputs.

4. Much research had been carried out since the 1980s-1990s at the Centre for the Study of Conflict (University of Ulster) at Queen's University and at the initiative of the Community Relation Council. However what Brandon Hamber seems to imply is that researchers were less visible publicly at the time.

5. Her Majesty's Prison Maze, also known as The Maze, Long Kesh, The H Blocks was used to intern paramilitary prisoners in Northern Ireland from 1971 to 2000. The two main Hunger Strikes of 1980 and 1981 took place there.

6. See: http://www.incore.ulst.ac.uk/research/projects/dipp/ (accessed on 8 October 2014).

7. http://www.incore.ulst.ac.uk/about/ (accessed on 8 October 2014).

8. The NIVT then CFNI was founded in 1979 to provide support to the voluntary and community sector in Northern Ireland.

9. The common characteristics between the two countries have been underlined especially in Johnston (1990).

10. Brian Nelson, a British agent and a member of the UDA, helped import weapons from South Africa. 
11. The Provisional IRA helped train the MK (ANC's Armed wing) in the handling of explosives in the late 1970 s and in 1980.

12. The MPs are all elected at Westminster: Sir Partick Cormack (Chairman), Conservative; Chritopher Fraser, Conservative ; Kate Hoey, Labour; Stephen Hepburn, Labour.

13. Body in charge of managing European Union Structural Funds In Northern Ireland and the Border Region of Ireland.

\section{ABSTRACTS}

In deeply-divided societies coming out of conflict the role of mediators from the "middleground" according to John Paul Lederach's theory is an asset. In Northern Ireland, the period following the Belfast Agreement of 1998 saw opportunities for such people to exert influence on policy making concerning contentious issues such as dealing with the past and reconciliation. This article aims at highlighting the role of Brandon Hamber, whose experience in South Africa helped shape his involvement in Northern Ireland. His position as both an outsider and insider provides an example of how policies are designed in transitional societies.

Selon le schéma de John Paul Lederach, le rôle des médiateurs issus de ce qu'il nomme la «position intermédiaire » est un atout majeur dans les sociétés divisées qui sortent d'un conflit intense. En Irlande du Nord, la période qui suit la signature de l'accord du Vendredi Saint de 1998, fut une aubaine pour ces acteurs qui ont pu exercer leur influence dans la mise en place de politiques visant à résoudre des questions conflictuelles liées au travail de mémoire et à la réconciliation. Cet article souhaite mettre en lumière le rôle de Brandon Hamber dont l'expérience sud-africaine a permis de construire son engagement en Irlande du Nord. En tant que personne à la fois de «l'extérieur » et de "l'intérieur» son exemple montre comment les politiques sont élaborées dans les sociétés en transition.

\section{INDEX}

Mots-clés: conflit nord-irlandais, élaboration des politiques, transferts culturels, société civile, travail de mémoire, réconciliation

Keywords: Northern Ireland conflict, policymaking, cultural transfers, civil society, dealing with the past, reconciliation

\section{AUTHOR}

\section{FABRICE MOURLON}

Université Paris 13, Sorbonne Paris Cité, Pléiade (EA 7338) 